\title{
Pembuatan Detail Desain Unmanned Surface Vehicle (USV) untuk Monitoring Wilayah Perairan Indonesia
}

\author{
Fajar Ramadhan dan Wasis Dwi Aryawan \\ Departemen Teknik Perkapalan, Fakultas Teknologi Kelautan, Institut Teknologi Sepuluh Nopember \\ (ITS) \\ e-mail:wasis@na.its.ac.id
}

\begin{abstract}
Abstrak-Indonesia merupakan negara maritim, dengan total luas wilayah laut terbesar di dunia. Sehingga diperlukannya kapal patroli sebagai kapal pengintai yang dapat menjaga kedaulatan wilayah laut Indonesia yang akhir - akhir ini sedang ramai diperbincangkan. Di era teknologi dan komunikasi yang semakin berkembang ini, tugas manusia semakin terbantu dengan hadirnya teknologi yang semakin berkembang pesat. Dimana teknologi ini sudah mulai masuk pada dunia transportasi yang salah satunya adalah teknologi kapal tanpa awak atau yang biasa disebut Unmanned Surface Vehicle. Katamaran merupakan jenis kapal dengan lambung banyak (multi-hull) yang dapat dikembangkan pada perairan Indonesia karena memiliki berbagai kelebihan. Dengan kecepatan tinggi, maka kapal diharuskan memiliki konstruksi yang kuat. Dalam perencanaan pembangunan kapal tanpa awak tersebut menggunakan sistem konstruksi melintang, dimana sistem konstruksi ini banyak digunakan pada kapal - kapal kecil pada umumnya (kurang dari 24 meter). Sehingga diperoleh berat ukuran konstruksi kapal tanpa awak tersebut sebesar 1,54 ton, dengan jarak gading sebesar $600 \mathrm{~mm}$, profil gading biasa menggunakan profil "I 50x6" dan "I 50x7" mm. Sedangkan profil gading besar menggunakan profil "L 60x40x5" dan "L 60x40x6" mm. Dari hasil tersebut, konstruksi katamaran kapal tanpa awak telah memenuhi standart kelas Biro Klasifikasi Indonesia tentang aturan konstruksi kapal kecil dibawah 24 meter dan perhitungan berat komponen konstruksi tidak melebihi dari displasmen kapal dengan sarat yang telah ditentukan. Biaya pembangunan kapal baru sebesar Rp 5.953.791.605,52 dengan spesifikasi sistem menggunakan sistem sebelumnya, sehingga kapal ini layak untuk dibangun.
\end{abstract}

Kata Kunci-Perairan Indonesia, kapal tanpa awak, katamaran, konstruksi melintang.

\section{PENDAHULUAN}

I NDONESIA dikenal sebagai Negara Maritim atau Negara Kepulauan terbesar di dunia dengan total luas negara sebesar $5.193 .250 \mathrm{~km}^{2}$ yang mencakup luas daratan dan lautan. Dimana dua per-tiga luas Indonesia adalah lautan dengan luasan sebesar $3.257 .483 \mathrm{~km}^{2}$. Dimana lautan Indonesia memiliki batas sesuai hukum laut Internasional dengan menggunakan teritorial laut sepanjang 12 mil laut serta Zona Ekonomi Eksklusif (ZEE) sepanjang 200 mil laut yang searah dengan penjuru mata angin [1]. Hal ini harus mendapat perhatian khusus dari pemerintah untuk mengamankan kedaulatan negara. Alat Utama Sistem Senjata atau dikenal dengan ALUTSISTA, menjadi kunci utama penjaga keamanan negara. Sehingga diperlukannya kapal patroli sebagai kapal pengintai yang dapat menjaga kedaulatan wilayah laut Indonesia yang akhir-akhir ini sedang ramai diperbincangkan. Sementara umlah kapal patroli, personil, dan dana yang dimiliki oleh TNI AL sangatlah terbatas. Namun, di era teknologi dan komunikasi yang semakin berkembang, tugas manusia semakin terbantu dengan hadirnya teknologi berupa kendaraan tanpa awak. Dimana teknologi tersebut diharapkan dapat membantu tugas manusia dalam menyelesaikan tugasnya. Kendaraan tanpa awak yang dapat bergerak pada permukaan air yaitu disebut dengan kapal tanpa awak atau Unmanned Surface Vehicle.

Pada pembuatan "Konsep Desain Unmanned Surface Vehicle $(U S V)$ ", perencanaan kapal patroli tersebut hanya sebatas konsep lambung katamaran yang akan digunakan. Konsep lambung tersebut hanya meliputi bentuk lambung katamaran yang dapat menampung komponen - komponen yang dapat membantu tugas TNI AL tersebut.

Unmanned surface vehicle harus memiliki bentuk dan konstruksi yang dapat mengapung di atas air dengan kecepatan dan kapasitas tertentu. Dalam proses pembuatan kapal tersebut, diperlukan sebuah sistem perancangan konstruksi, bentuk dan desain detail yang sempurna. Oleh karena itu, pada Jurnal ini akan dibahas mengenai bentuk konstruksi katamaran dalam membantu tugas TNI AL untuk memonitoring perairan Indonesia sebagai lanjutan dari pembuatan "Konsep Desain Unmanned Surface Vehicle (USV)".

\section{TINJAUAN PUSTAKA}

\section{A. Unmanned Surface Vehicle}

Unmanned Surface Vehicle (USV) atau Autonomous Surface Vehicle (ASV) merupakan sebuah wahana tanpa awak yang dapat dioperasikan pada permukaan air [2]. USV dikendalikan otomatis melalui Ground Control Station (GCS) secara real time melalui telemetri dengan di operasikan secara manual maupun memberikan masukan waypoint / lokasi lokasi yang akan dituju.

Kapal tanpa awak tidak hanya digunakan sebagai kapal militer, melainkan dapat digunakan sebagai kapal riset, survey, inspeksi keadaan sekitar sungai, survey seismic, operasi 
penyelamatan, dan masih banyak lainnya. Pada saat ini, Indonesia merupakan salah satu negara yang sedang banyak melakukan penelitian mengenai Unmanned Surface Vehicle (USV). Baik dari segi elektronik maupun dari segi bentuk maupun appendages kapal tersebut.

Dalam pembuatan kapal tanpa awak, perangkat sistem propulsi maupun sistem tambahan yang digunakan dalam kapal tersebut dapat menyesuaikan dengan tugas yang akan dilakukan oleh kapal tanpa awak tersebut. Sehingga sistem yang terintegrasi pada kapal dan control ground station harus dapat memenuhi kriteria pengiriman jarak jauh operasional pada kapal tanpa awak tersebut.

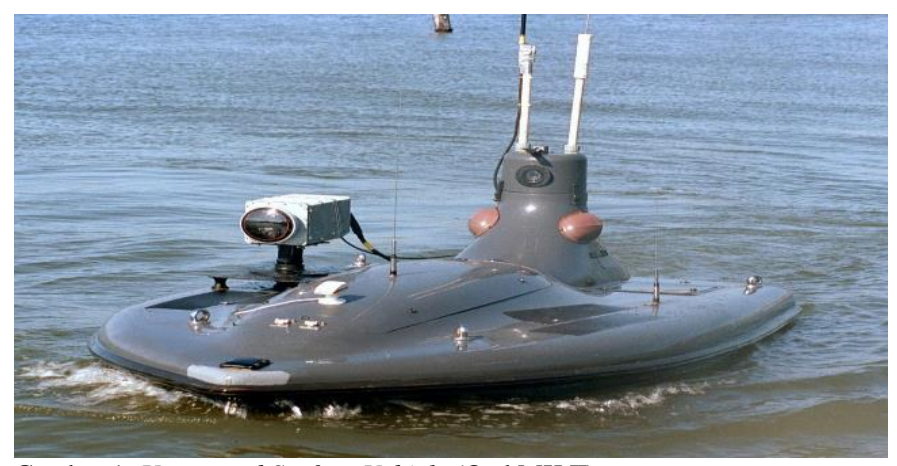

Gambar 1. Unmanned Surface Vehicle (Owl MK II)

\section{B. Aluminium Alloy}

Pelat Aluminium adalah bahan logam berbentuk lembaran yang ringan dan kuat serta mudah dalam pengerjaan dan perawatan. Pelat aluminium sangat cocok digunakan di daerah tropis karena memiliki sifat yang tahan terhadap segala cuaca serta tidak mudah terbakar. Pelat aluminium ini juga mudah di bentuk dan dikerjakan. Pelat aluminium tersebut telah menjadi pilihan utama sebagai material yang sangat dibutuhkan dibanyak bidang industry serta harganya yang lebih murah dibandingkan dengan stainless steel.

Adapun jenis - jenis unsur paduan dalam material aluminium alloy antara lain:

- Magnesium $(\mathrm{Mg})$

- Silikon (Si)

- Tembaga $(\mathrm{Cu})$

- Nikel (Ni)

- Mangan (Mn)

- Seng (Zn)

- Ferro (Fe)

- Titanium (Ti)

Aluminium alloy telah menjadi bahan alternatif yang dapat digunakan sebagai bahan lambung kapal. Namun, pelat aluminium alloy juga memiliki beberapa kekurangan dari bahan lainnya. Seperti dalam pengerjaannya membutuhkan tenaga kerja khusus dan tidak dapat digabungkan dengan material logam yang mempunyai beda jenis (bisa mempercepat korosi kimiawi).

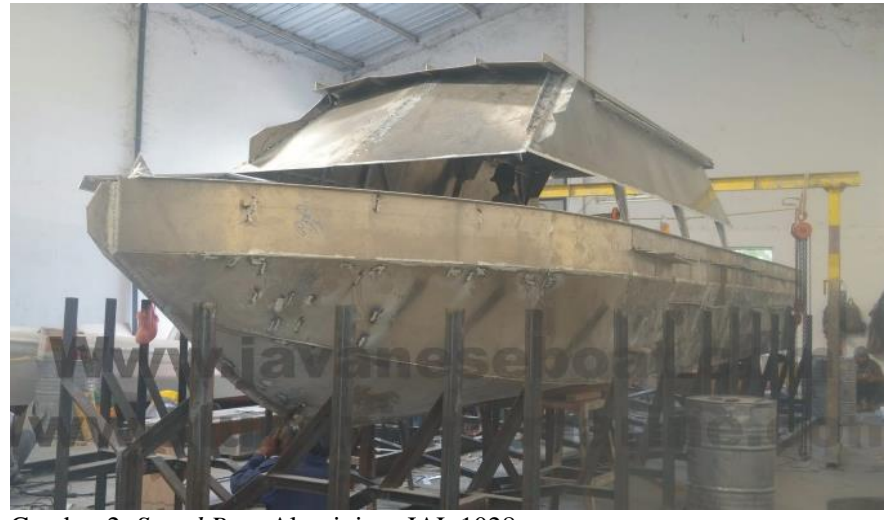

Gambar 2. Speed Boat Aluminium JAL 1028

\section{Sistem Konstruksi Kapal}

Konstruksi secara umum berarti komponen - komponen suatu bangunan yang mendukung kekuatan bangunan tersebut agar tetap kokoh sesuai dengan desain. Dalam bidang perkapalan, konstruksi kapal merupakan komponen komponen pada bangunan kapal yang mana terdiri dari badan kapal beserta bangunan atas (super structure). Dalam proses pembangunan kapal di galangan, pekerjaan didahului dengan mendesain konstruksi dan dilanjutkan dengan pembangunan konstruksi kapal yang diawali dengan peletakan lunas, dilanjutkan dengan konstruksi rangka / gading - gading, kulit kapal, geladak, dan kemudian anjungan maupun bangunan atas kapal. Namun, ada juga beberapa kondisi yang tidak mewajibkan dalam pembangunan kapal sesuai dengan pembangunan kapal secara umum dikarenakan ada komponen yang sulit untuk dilakukan pengerjaan sehingga ada perlakuan khusus pada sistem konstruksi tersebut. Sistem konstruksi pada kapal secara umum terbagi atas beberapa macam sistem konstruksi, yaitu sistem konstruksi memanjang, melintang dan campuran.

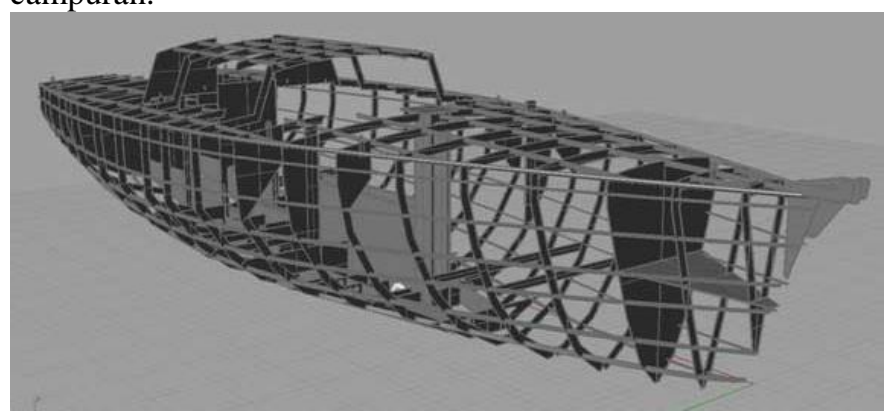

Gambar 3. Desain Konstruksi pada Kapal

Pada dasarnya, pemilihan jenis sistem konstruksi suatu kapal sangat ditentukan oleh beberapa faktor seperti halnya ukuran kapal, jenis kapal ataupun fungsi kapal tersebut. Sehingga hal tersebut dapat dijadikan dasar pertimbangan dalam pemilihan sistem konstruksi kapal yang akan dibuat. Sistem konstruksi pada kapal terbagi menjadi 3 bagian, yaitu bagian konstruksi alas / dasar, bagian konstruksi lambung / sisi, dan bagian konstruksi geladak.

Perhitungan konstruksi kapal kecil dapat mengacu pada buku Biro Klasifikasi Indonesia Vol. VII mengenai "Rules for Small Vessels up to 24 m" tahun 2013. 


\section{Stabilitas Kapal}

Stabilitas dapat diartikan sebagai kemampuan kapal untuk kembali ke keadaan semula setelah dikenai oleh gaya luar. Kemampuan tersebut dipengaruh oleh lengan dinamis (GZ) yang membentuk momen kopel yang menyeimbangkan gaya tekan ke atas dengan gaya berat. Komponen stabilitas terdiri dari GZ, KG dan GM. Dalam perhitungan stabilitas, yang paling penting adalah mencari harga lengan dinamis (GZ).

Kapal yang akan dibangun harus dapat dibuktikan secara teoritis bahwa kapal tersebut memenuhi standart keselamatan Safety of Life at Sea (SOLAS) atau International Maritime Organization (IMO). Kapal yang memiliki kecepatan tinggi dalam perhitungan stabilitas harus memiliki nilai yang tidak melebihi dari peraturan High Speed Craft. Berdasarkan IMO HSC Code 2000-MSC 97(73), HSC 2000 Multihull Annex 7. Intact. Kriteria yang digunakan dalam penelitian ini adalah, Area 0 to 30 derajat dan Angle of max, GZ adalah:

1. Luasan dibawah kurva GZ tidak boleh kurang dari 0,005 meter radian sampai dengan sudut oleng 30 derajat dan tidak boleh kurang dari 0,090 meter radian sampai dengan sudut oleng 40 derajat. Selain itu area di bawah kurva GZ antara sudut oleng 30 derajat dan 40 derajat tidak boleh kurang dari0,030 meter radian.

2. Lengan stabilitas statis GZ paling kecil adalah 0,2 meter pada sudut oleng sama dengan atau lebih besar dari 30 derajat.

3. Lengan stabilitas maksimum GZ max sebaiknya terjadi pada sudut oleng dari 25 derajat.

4. Tinggi metasenta (MG) tidak kurang dari 0,15 derajat.

\section{METODOLOGI PENELITIAN}

Diagram alir (flowchart) metodologi dalam pengerjaan Jurnal ini dapat dilihat pada Gambar 4 dibawah ini.

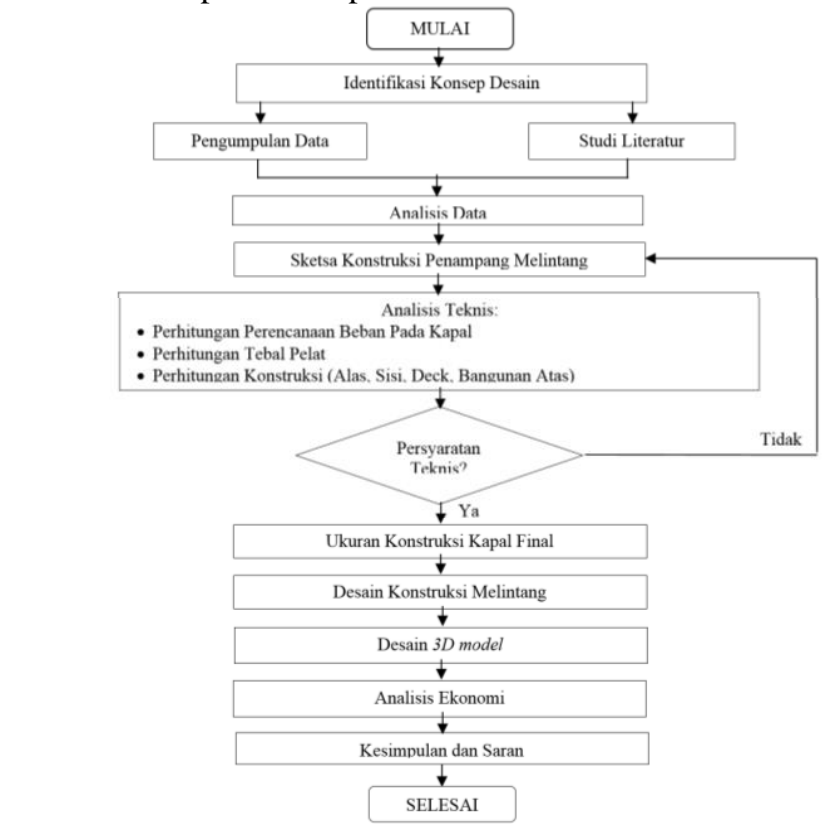

Gambar 4. Diagram alir pengerjaan Jurnal

\section{ANALISIS TEKNIS DAN PEMBAHASAN}

\section{A. Penentuan Jenis Aluminium Alloy}

Dalam perencanaan pembangunan $U S V$ ini digunakan untuk memenuhi kebutuhan militer sebagai kapal patroli yang berfungsi untuk monitoring wilayah perairan Indonesia tanpa adanya komponen tempur atau senjata yang terpasang pada kapal tersebut. Perencanaan jenis material yang akan digunakan sebagai material utama lambung tersebut yaitu menggunakan material aluminium. Pemilihan material ini berdasarkan kriteria desain yang akan dibuat dimana kapal harus memiliki kemampuan kamuflase, dan pemilihan material ini dikarenakan telah teruji dan sudah banyak digunakan untuk kapal Angkatan Laut di dunia [3].

Pelat Aluminium adalah bahan logam berbentuk lembaran yang ringan dan kuat serta mudah dalam pengerjaan dan perawatan. Pelat aluminium sangat cocok digunakan di daerah tropis karena memiliki sifat yang tahan terhadap segala cuaca serta tidak mudah terbakar. Pelat aluminium ini juga mudah di bentuk dan dikerjakan. Aluminium telah menjadi bahan alternatif yang dapat digunakan sebagai bahan lambung kapal. Dimana aluminium mempunyai beberapa keunggulan yang telah disebutkan sebelumnya, dan memiliki beberapa kekurangan dari bahan lainnya. Seperti dalam pengerjaannya membutuhkan tenaga kerja khusus dan tidak dapat digabungkan dengan material logam yang mempunyai beda jenis (bisa mempercepat korosi kimiawi).

Berikut ini merupakan tabel perbandingan antara ke empat series aluminium alloy yang sering digunakan pada pembuatan lambung kapal di galangan:

Tabel 1.

Perbandingan Aluminium Series

\begin{tabular}{ccccc}
\hline \hline Alloying Elements & 5083 & 5086 & 6061 & 6082 \\
\hline Magnesium & $4,0-4,9$ & $3,5-4,5$ & $0,8-1,2$ & $0,6-1,2$ \\
Silikon & 0,40 & 0,40 & $0,4-0,8$ & $0,7-1,3$ \\
Kupfer & 0,10 & 0,10 & $0,15-0,4$ & 0,10 \\
Iron & 0,40 & 0,50 & 0,70 & 0,50 \\
Manganese & $0,4-1,0$ & $0,2-0,7$ & 0,15 & $0,4-1,0$ \\
Zinc & 0,25 & 0,25 & 0,25 & 0,25 \\
Chrome & $0,05-0,25$ & $0,05-0,25$ & $0,04-0,35$ & 0,25 \\
Titan & 0,15 & 0,15 & 0,15 & 0,10 \\
\hline \hline
\end{tabular}

Pada Tabel 1 dapat disimpulkan bahwa kandungan magnesium terbesar dimiliki oleh aluminium series 5083, dimana dengan adanya kandungan magnesium yang berlebih menyebabkan aluminium alloys tersebut memiliki sifat tahan korosi yang baik, mudah dilas serta dapat menambah kekuatan yang cukup bagi aluminium alloy tersebut.

Namun, unsur silikon mempunyai koefisien panas yang rendah sehingga dapat menyebabkan kualitas pengerjaan mesin yang jelek. Kandungan Manganese pada aluminium alloy juga dapat membuat aluminium alloy tersebut mudah untuk dibentuk.

Jadi, dapat disimpulkan bahwa keempat series aluminium alloy tersebut yang memiliki sifat baik dalam perencanaan pembangunan kapal tanpa awak tersebut dapat menggunakan aluminium series 5083. Karena aluminium alloy series tersebut memiliki banyak sifat positif yang diberikan dalam kandungannya. Selain itu aluminium alloy series 5083 tersebut 
juga sudah banyak dijual di pasaran, sehingga dalam proses pembuatan kapal tanpa awak tersebut tidak akan mengalami kendala yang cukup lama dalam mendatangkan material aluminium alloy series tersebut.

\section{B. Penentuan Jenis Konstruksi}

Macam - macam konstruksi pada kapal biasanya terdiri atas 3 macam sistem konstruksi, yaitu sistem konstruksi memanjang, sistem konstruksi melintang dan sistem konstruksi campuran. Berdasarkan ketiga macam sistem konstruksi tersebut memiliki sifat dan kegunaan yang berbeda - beda tergantung pada fungsi maupun ukuran dari kapal yang akan dibangun.

Adapun ukuran utama kapal USV yang akan dibuat memliki ukuran sebagai berikut [3]:

$$
\begin{array}{llll}
\mathrm{L}_{\mathrm{H}} & =7,640 \mathrm{~m} & \mathrm{H}=1,150 \mathrm{~m} \\
\mathrm{~B} & =3,500 \mathrm{~m} & \mathrm{~B} 1=1,000 \mathrm{~m} \\
\mathrm{~T} & =0,500 \mathrm{~m} & & \\
\mathrm{~S} & =1,500 \mathrm{~m}
\end{array}
$$

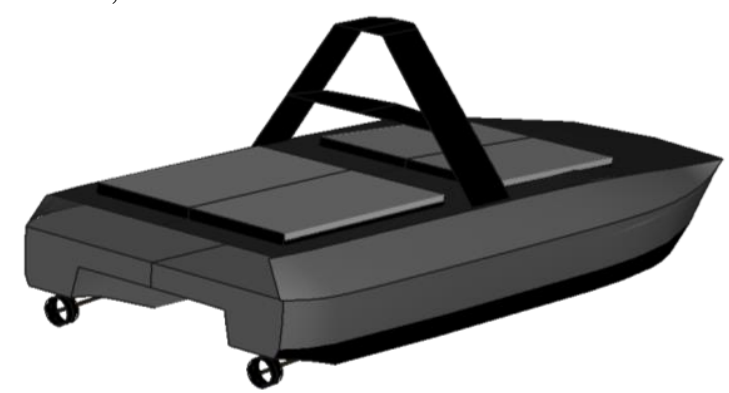

Gambar 5. Konsep Desain Unmanned Surface Vehicle (USV)

Berdasarkan hasil ukuran utama kapal yang telah didapatkan dan studi literatur mengenai sistem konstruksi kapal, maka sistem konstruksi kapal yang akan digunakan yaitu menggunakan sistem konstruksi melintang. Dimana keuntungan penggunaan dari sistem konstruksi tersebut yaitu konstruksinya sederhana, kekuatan kapal sangat baik, mudah dalam pembangunannya, dan sistem konstruksi tersebut hanya digunakan pada kapal berukuran kecil dimana kekuatan memanjang kapal akibat momen lengkung kapal tidak berbahaya. Sedangkan kelemahan dari sistem konstruksi memanjang kapal yaitu konstruksinya lebih rumit dan susah dalam pembangunannya.

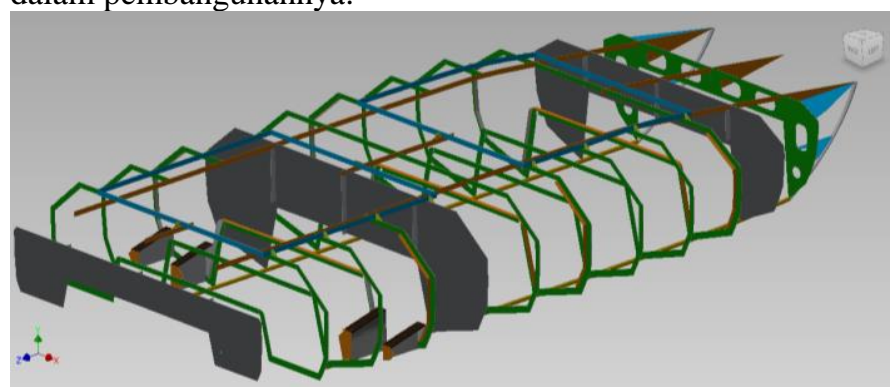

Gambar 6. Sistem Konstruksi Unmanned Surface Vehicle (USV)

\section{Perhitungan Konstruksi Kapal Kecil}

Perhitungan konstruksi kapal kecil dapat mengacu pada perhitungan konstruksi pada peraturan Biro Klasifikasi Indonesia Vol. VII mengenai "Rules for Small Vessels up to 24 m". Dalam perhitungan konstruksi, hal pertama yang harus dilakukan yaitu mencari besarnya beban - beban yang bekerja pada seluruh bagian lambung kapal. Untuk rumus pada tiap beban dapat dilihat pada buku BKI.

Tabel 2.

Rekapitulasi Beban pada Lambung Kapal

\begin{tabular}{ccc}
\hline \hline Bagian Lambung & $<0,4 \mathrm{~L}:$ aft & $\geq 0,4 \mathrm{~L}:$ fore \\
\hline Bawah Lambung & $18,333 \mathrm{kN} / \mathrm{m}^{2}$ & $22,919 \mathrm{kN} / \mathrm{m}^{2}$ \\
Samping Lambung & $12,315 \mathrm{kN} / \mathrm{m}^{2}$ & $15,428 \mathrm{kN} / \mathrm{m}^{2}$ \\
Main Deck & $10,1302 \mathrm{kN} / \mathrm{m}^{2}$ \\
Deck Cabins & $9,1285 \mathrm{kN} / \mathrm{m}^{2}$ \\
Wall Cabins & $10,1302 \mathrm{kN} / \mathrm{m}^{2}$ \\
Geladak Penghubung & $16,209 \mathrm{kN} / \mathrm{m}^{2}$ \\
\hline \hline
\end{tabular}

Dalam pembuatan kapal tanpa awak tersebut, material yang digunakan berupa aluminium alloy. Berdasarkan pemilihan jenis aluminium yang sudah dipilih maka aluminium yang akan digunakan memiliki series 5083, dimana series tersebut memiliki sifat yang cukup baik. Sifat material aluminium alloy

\begin{tabular}{|c|c|c|c|c|c|c|}
\hline \multirow{2}{*}{$\begin{array}{l}\text { Alloying } \\
\text { Number }\end{array}$} & \multirow{2}{*}{$\begin{array}{l}\text { Material } \\
\text { condition }\end{array}$} & \multirow{2}{*}{$\begin{array}{c}\text { Yield } \\
\text { strength } \\
\mathrm{R}_{\mathrm{p} 0.2} \\
{\left[\mathrm{~N} / \mathrm{mm}^{2}\right]} \\
\mathrm{min} .\end{array}$} & \multirow{2}{*}{$\begin{array}{c}\text { Tensile } \\
\text { strength } \\
\mathrm{R}_{\mathrm{m}} \\
{\left[\mathrm{N} / \mathrm{mm}^{2}\right]}\end{array}$} & \multirow{2}{*}{$\begin{array}{c}\text { Thickness } \\
\mathrm{t} \\
{[\mathrm{mm}]}\end{array}$} & \multicolumn{2}{|c|}{$\begin{array}{c}\text { Elongation } \\
{[\%]}\end{array}$} \\
\hline & & & & & $\mathrm{A}_{50 \mathrm{~mm}}$ & A \\
\hline KI AW-5059 & H112 & 200 & $\geq 330$ & $3 \leq \mathrm{t} \leq 50$ & - & 10 \\
\hline \multirow[t]{2}{*}{ KI AW-5083 } & O/H111 & 110 & $270-350$ & $\mathrm{t} \leq 12.5$ & 10 & - \\
\hline & H112 & 125 & $>270$ & $t>12.5$ & - & 12 \\
\hline \multirow[t]{2}{*}{ KI AW-5086 } & $\mathrm{O} / \mathrm{H} 111$ & 95 & $240-320$ & $\mathrm{t} \leq 12.5$ & 15 & - \\
\hline & H112 & 95 & $240-320$ & $t>12.5$ & - & 18 \\
\hline \multirow[t]{2}{*}{ KI AW-5383 } & $\mathrm{O} / \mathrm{H} 111$ & 145 & $\geq 290$ & $3 \leq \mathrm{t} \leq 50$ & - & 17 \\
\hline & H112 & 190 & $\geq 310$ & $3 \leq \mathrm{t} \leq 50$ & - & 13 \\
\hline \multirow[t]{2}{*}{ KI AW-6005 } & T5/T6 & 215 & $\geq 260$ & $\mathrm{t} \leq 12.5$ & 8 & - \\
\hline & & 215 & $\geq 260$ & $t>12.5$ & - & 6 \\
\hline \multirow[t]{2}{*}{ KI AW-6061 } & T5/T6 & 240 & $\geq 260$ & $\mathrm{t} \leq 12.5$ & 10 & - \\
\hline & & 240 & $\geq 260$ & $t>12.5$ & - & 8 \\
\hline \multirow[t]{2}{*}{ KI AW-6082 } & T5/T6 & 260 & $\geq 310$ & $\mathrm{t} \leq 12.5$ & 10 & - \\
\hline & & 260 & $\geq 310$ & $t>12.5$ & - & 8 \\
\hline
\end{tabular}
berdasarkan kekuatannya dapat dilihat pada tabel 3 .

Tabel 3.

Sifat Material Aluminium Alloy

Berdasarkan sifat material setiap aluminium alloy pada tabel 3, maka diperoleh:

$$
\begin{aligned}
& \mathrm{R}_{\mathrm{p} 0,2}=110 \mathrm{~N} / \mathrm{mm}^{2} \\
& \mathrm{R}_{\mathrm{m}}=270 \mathrm{~N} / \mathrm{mm}^{2}
\end{aligned}
$$

Sehingga nilai material faktor sebesar:

$$
\mathrm{k}=\frac{635}{\mathrm{R}_{\mathrm{p} 0,2}+\mathrm{R}_{\mathrm{m}}}=1,671
$$

Salah satu sifat umum aluminium alloy adalah tahan korosi terhadap segala cuaca. Dengan sifat aluminium yang tahan

\begin{tabular}{|c|c|c|c|c|c|}
\hline \multirow{2}{*}{ No. } & \multirow{2}{*}{ Item } & \multicolumn{2}{|c|}{ Untuk : <0.4 L } & \multicolumn{2}{|c|}{ Untuk $: \geq 0.4 \mathrm{~L}$} \\
\hline & & Perhitungan & Diambil & Perhitungan & Diambil \\
\hline \multirow[t]{3}{*}{1.} & Pelat Lunas & & & & \\
\hline & Lebar & $732,12 \mathrm{~mm}$ & $750 \mathrm{~mm}$ & $732,12 \mathrm{~mm}$ & $750 \mathrm{~mm}$ \\
\hline & Tebal & $8,96 \mathrm{~mm}$ & $9 \mathrm{~mm}$ & $8,96 \mathrm{~mm}$ & $9 \mathrm{~mm}$ \\
\hline 2. & Pelat Alas & $6,96 \mathrm{~mm}$ & $8 \mathrm{~mm}$ & $7,78 \mathrm{~mm}$ & $8 \mathrm{~mm}$ \\
\hline \multirow[t]{3}{*}{3.} & Wrang / Floor & & & & \\
\hline & Modulus & $8,18 \mathrm{~cm}^{3}$ & $9 \mathrm{~cm}^{3}$ & $10,22 \mathrm{~cm}^{3}$ & $11 \mathrm{~cm}^{3}$ \\
\hline & Dimensi & I & $65 \times 6 \mathrm{~mm}$ & I & $65 \times 7 \mathrm{~mm}$ \\
\hline 4. & Pelat Sisi & $4,82 \mathrm{~mm}$ & $6 \mathrm{~mm}$ & $5,40 \mathrm{~mm}$ & $6 \mathrm{~mm}$ \\
\hline 5. & Pelat Bridge & $7,89 \mathrm{~mm}$ & $8 \mathrm{~mm}$ & $7,89 \mathrm{~mm}$ & $8 \mathrm{~mm}$ \\
\hline \multirow[t]{3}{*}{6.} & Gading Besar & & & & \\
\hline & Modulus & $14,84 \mathrm{~cm}^{3}$ & $16 \mathrm{~cm}^{3}$ & $18,59 \mathrm{~cm}^{3}$ & $25 \mathrm{~cm}^{3}$ \\
\hline & Dimensi & $\mathrm{L}$ & $60 \times 40 \times 5 \mathrm{~mm}$ & $\mathrm{~L}$ & $60 \times 40 \times 6 \mathrm{~mm}$ \\
\hline
\end{tabular}
terhadap korosi maka material aluminium tidak memerlukan penambahan tebal akibat korosi $\left(t_{k}=0\right)$ [4]. Daya tahan terhadap korosi juga dapat ditambahkan dengan memberi cat pada aluminium alloy tersebut.

Tabel 4.

Rekapitulasi Konstruksi pada Lambung Kapal 


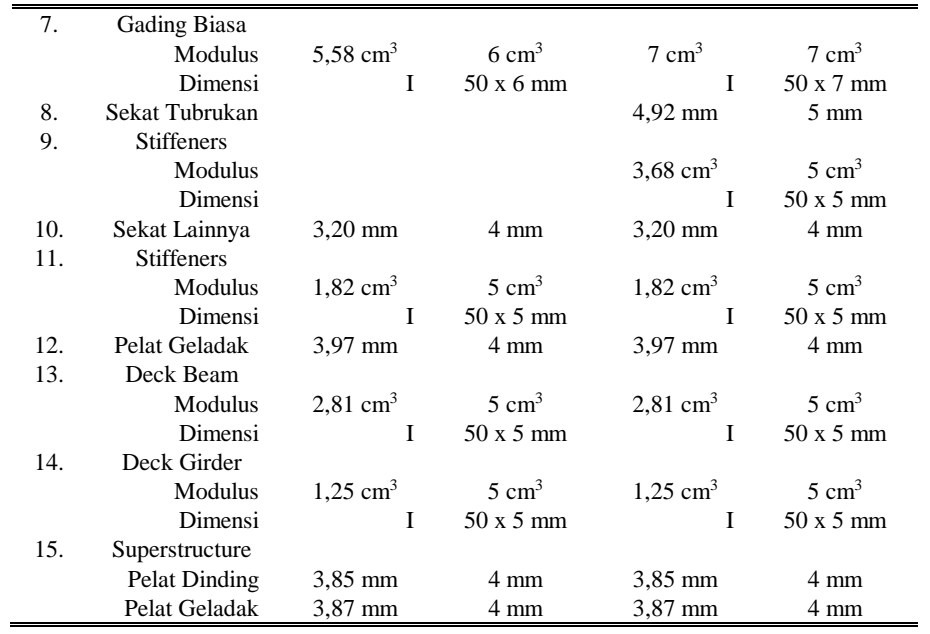

Setelah mendapatkan beban yang bekerja pada tiap - tiap bagian lambung kapal, maka perhitungan detail konstruksi dapat dilanjutkan dengan mengacu pada peraturan Biro Klasifikasi Indonesia Vol. VII. Sehingga diperoleh besarnya ukuran konstruksi lambung kapal tersebut seperti pada tabel 4.

\section{Perhitungan dan Perencanaan Bulkheads}

Dalam perencanaan sekat tubrukan pada kapal, jika sistem penggerak menggunakan motor tanpa layar, maka kapal yang kurang dari 17 meter dapat ditambahkan maupun tidak menggunakan sekat tubrukan [4]. Maka dalam perencanaannya akan di pasang sekat tubrukan meskipun panjang kapal hanya 7,2 m. Dimana jarak sekat tubrukan dapat dipasang pada jarak 0,05 L dari FP sampai 0,05 L + 3 m dari FP. Pada perencanaan kali ini maka letak sekat tubrukan dapat diambil pada jarak 1,177 m dari FP (frame spacing di station 10).

Demi meningkatkan pengamanan kapal dari kebocoran maka penambahan sekat kedap dapat ditambahkan pada bagian kompartmen mesin. Sehingga jumlah total sekat yang diambil sebanyak 2 buah, yaitu sekat tubrukan dan sekat depan kamar mesin.
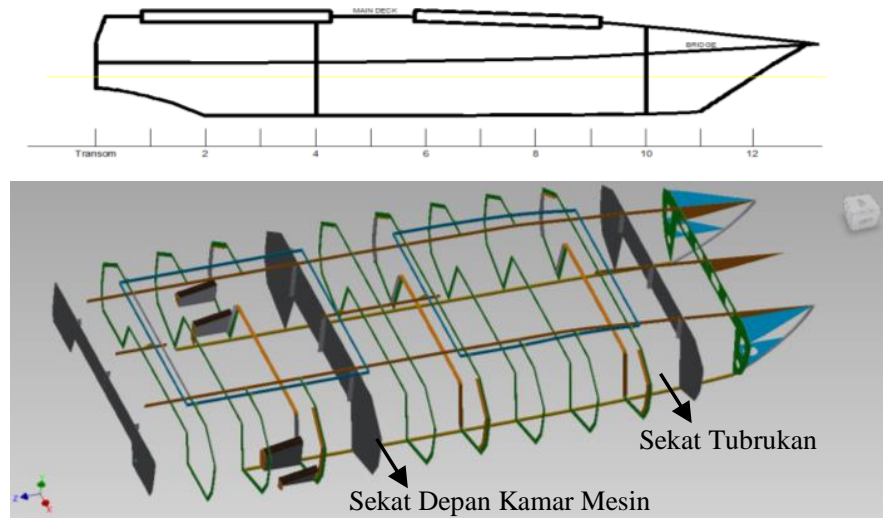

Gambar 7. Perencanaan Sekat pada Kapal Tanpa Awak

\section{E. Pembuatan Penampang Melintang Kapal}

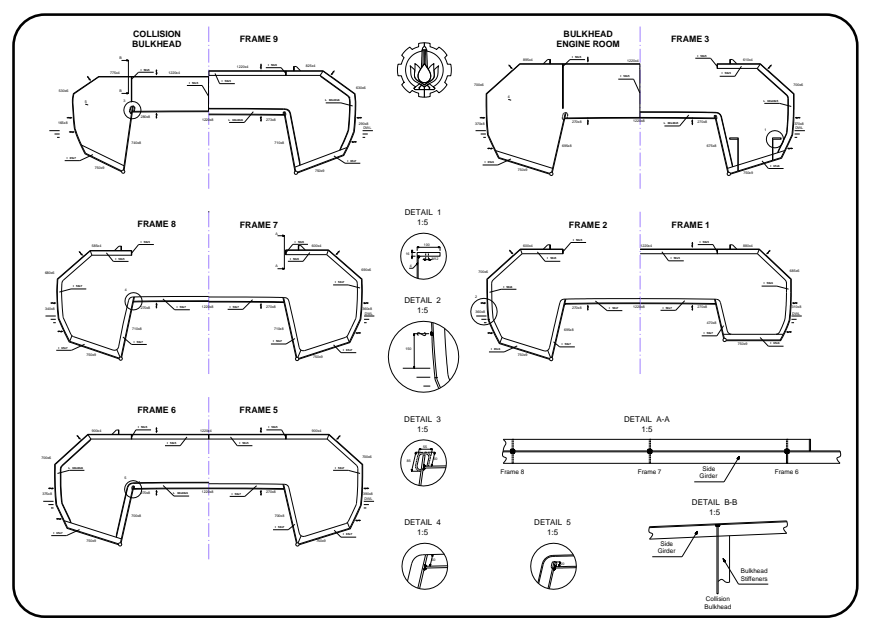

Gambar 8. Penampang Melintang Konstruksi Kapal

Setelah semua perhitungan konstruksi selesai, langkah selanjutnya adalah pembuatan Penampang Melintang Kapal atau Midship Section. Berikut merupakan gambar penampang melintang konstruksi kapal pada Gambar 8.

\section{F. Perhitungan Koreksi Berat Kapal}

Perhitungan koreksi berat kapal dilakukan guna untuk memperoleh kondisi kapal sebenarnya setelah dilakukan penambahan perhitungan konstruksi kapal. Perhitungan berat aluminium kapal awal hanya secara pendekatan. Sedangkan perhitungan koreksi berat aluminium kapal dilakukan dengan cara menghitung setiap gading, pelat, dan profil yang akan digunakan sesuai dengan rekapitulasi konstruksi maupun gambar melintang kapal.

Berdasarkan kedua hasil perhitungan berat aluminium tersebut, diperoleh selisih berat konstruksi dan kulit kapal sebesar 14\%. Namun, pada komponen berat lainnya tidak mengalami perubahan akibat perencanaan konstruksi kapal. Sehingga perlu dilakukan perhitungan koreksi displasmen pada kapal akibat perencanaan konstruksi kapal. Adapun perhitungan kondisi kapal adalah sebagai berikut:

\begin{tabular}{ccc}
\hline \hline & Konsep Desain & Detail Desain \\
\hline Displacement & 4,083 ton & \\
Berat Aluminium & 1,349 ton & 1,540 ton \\
Berat Total & & 3,982 ton \\
Selisih Berat dan Displ & & 0,101 ton \\
Margin & & $2,5 \%$ \\
\hline \hline
\end{tabular}

Dari perhitungan yang dilakukan didapatkan margin berat kapal sebesar 2,5\%. Sehingga kapal masih dapat mengapung akibat besarnya displasmen kapal yang masih terpenuhi dengan berat kapal total sebesar 3,982 ton.

\section{G. Perhitungan Koreksi Trim dan Stabilitas Kapal}

Dikarenakan pada penambahan konstruksi menyebabkan perpindahan item dengan posisi yang berbeda maka perlu adanya perhitungan koreksi trim dan stabilitas kapal. Dimana barang yang mengalami perubahan posisi yaitu baterai yang terdapat pada bagian tengah kapal (midship). 
Dengan menggunakan kriteria NCVS, di mana trim kapal tidak boleh melebihi nilai Lpp/50 [5]. Untuk hasil nilai trim dapat dilihat pada Tabel 5 .

Tabel 5.

Rekapitulasi Konstruksi pada Lambung Kapal

\begin{tabular}{ccccc}
\hline \hline No. & Kondisi & Batasan & Nilai & Status \\
\hline 1 & Loadcase 1 & 0,138 & 0,1 & Diterima \\
\hline \hline
\end{tabular}

Sedangkan dalam perhitungan stabilitas kapal, kriteria kondisi pemuatan (loadcase) yang digunakan pada perhitungan ini mengacu pada standar International Code of Safety for High Speed Craft (2000)[6]. Perhitungan stabilitas dilakukan dengan bantuan software Maxsurf Stability Enterprise Education Version. Tabel 6 merupakan hasil perhitungan.

Tabel 6.

Perhitungan Stabilitas

\begin{tabular}{cccc}
\hline \hline Data & Loadcase I & Kriteria HSC & Kondisi \\
\hline $\begin{array}{c}\mathrm{e} 0-30^{\circ} \\
(\mathrm{m} . \mathrm{deg})\end{array}$ & 22,4569 & $\geq 3,1513$ & Diterima \\
$\mathrm{Hw}$ & 0 & $\leq 10$ & Diterima \\
$(\mathrm{deg})$ & 31,8 & $\geq 10$ & Diterima \\
$\begin{array}{c}\theta \mathrm{max} \\
(\mathrm{deg})\end{array}$ & & \\
\hline \hline
\end{tabular}

\section{H. Perhitungan Estimasi Biaya Pembangunan Kapal}

Biaya pembangunan kapal terdiri dari biaya kebutuhan material, sistem propulsi dan sistem pengintai. Dimana pehitungan biaya material berdasarkan kebutuhan material tiap gading dan pelat kapal. Sedangkan kebutuhan sistem propulsi dan pengintai mengacu pada "Konsep Desain". Sehingga kebutuhannya pelat yang dibeli lebih akurat. Setelah dilakukan perhitungan, didapatkan biaya pembangunan awal sebesar Rp 4.510.448.186,00 dengan nilai tukar USD terhadap Rupiah senilai Rp 13.388 dan nilai tukar EURO terhadap Rupiah senilai Rp 15.174 pada 17 Juni 2017.

Selain itu dibutuhkannya biaya koreksi dalam pembangunan sebuah kapal [7]. Sehingga total keseluruhan biaya pembangunan kapal Unmanned Surface Vehicle (USV) sebesar Rp 5.953.791.605,52.

\section{KESIMPULAN}

Setelah dilakukan perhitungan dan analisis teknis, maka kesimpulan dari Jurnal ini adalah sebagai berikut:

1.Pemilihan aluminium alloy yang digunakan pada pembuatan lambung kapal USV "PLAT -N" menggunakan series 5083 dikarenakan memiliki sifat mekanik yang lebih baik dari series lainnya.

2. Konstruksi yang digunakan pada kapal USV tersebut menggunakan sistem konstruksi melintang dengan rincian profil yang digunakan sebagai berikut:

- Wrang : I 65x6 dan I 65x7 mm

- Gading Besar : L 60x40x5 dan L 60x40x6 mm

- Gading Biasa : I 50x6 dan I 50x7 mm

3. Desain Konstruksi Penampang Melintang, dan 3D Model telah dibuat.

5. Berdasarkan Analisis Ekonomis biaya pembangunan yang dilakukan, didapatkan biaya investasi pembangunan USV "PLAT-N" sebesar Rp 5.593.791.605,52.

\section{UCAPAN TERIMA KASIH}

Penulis mengucapkan terima kasih kepada Biro Klasifikasi Indonesia yang telah memperkenankan pengunduhan peraturan klasifikasi berupa buku secara gratis pada webresmi BKI.

\section{DAFTAR PUSTAKA}

[1] Wikipedia, "Indonesia," Wikipedia, 2016. [Online]. Available: http://www.id.wikipedia.org/wiki/Indonesia.

[2] Wikipedia, "Unmanned Surface Vehicle," wikipedia, 2017. [Online]. Available: https://en.wikipedia.org/wiki/Unmanned_surface_vehicle.

[3] D. Hardianto, "Pembuatan Konsep Desain Unmanned Surface Vehicle (USV) untuk Monitoring Wilayah Perairan Indonesia," Publ. Ilm. Online Mhs. ITS, vol. 6, no. 2, 2017.

[4] B. K. Indonesia, Rules for Small Vessels up to 24m. Jakarta, 2013.

[5] K. Perhubungan, Non-Convention Vessel Standart (NCVS) Indonesian Flagged. Jakarta: Kementrian Perhubungan Republik Indonesia, 2009.

[6] T. M. and C. Agency, International Code of Safety for High-Speed Craft (2000. London: TSO, 2000.

D. Watson, "Practical Ship Design," Elsevier, vol. 1, 1998. 